\title{
Sugammadex use in patients with end-stage renal disease: a historical cohort study
}

\section{Utilisation de sugammadex chez les patients atteints d'insuffisance rénale terminale : une étude de cohorte historique}

\author{
Stephania Paredes, MD - Steven B. Porter, MD - Ivan E. Porter II, MD • \\ J. Ross Renew, MD, FASA, FASE (1)
}

Received: 27 April 2020/Revised: 2 July 2020/ Accepted: 5 July 2020/Published online: 18 September 2020

(C) Canadian Anesthesiologists' Society 2020

\begin{abstract}
Purpose While sugammadex (SGX) is not approved for use in patients with end-stage renal disease (ESRD), its administration in this patient population has been reported. We designed the current study to review all instances of patients with ESRD receiving SGX and to describe their clinical outcomes.

Methods This is a historical cohort study of 219 patients with chronic kidney disease stage 5 who received SGX in one of three hospital locations within the same academic health system. Data were collected between 7 March 2016 and 1 August 2019 and included demographics, notable events from the anesthesia records, and postoperative complications. The primary outcome included any complication possibly related to SGX such as hypersensitivity reactions, need for reintubation, hypoxemia, pneumonia, and residual neuromuscular blockade. Secondary outcomes included any other complication not included in the primary outcome and/or patient mortality within 30 days after the procedure.

Results No patient experienced a hypersensitivity reaction. Three patients required reintubation while two patients developed hypoxemia that did not require reintubation. One patient developed hospital-acquired pneumonia. Fifty (23\%) patients developed other
\end{abstract}

S. Paredes, MD $\cdot$ S. B. Porter, MD

J. R. Renew, MD, FASA, FASE ( $\square)$

Department of Anesthesiology and Perioperative Medicine,

Mayo Clinic College of Medicine, 4500 San Pablo Road,

Jacksonville, FL, USA

e-mail: renew.j@mayo.edu

I. E. Porter II, MD

Division of Nephrology \& Hypertension, Mayo Clinic College of Medicine, Jacksonville, FL, USA postoperative complications (different from our primary outcome) and nine patients (4\%) died during the subsequent 30 postoperative days. None of the primary or secondary outcomes appeared to be related to SGX use. Conclusions We provide incremental evidence that $S G X$ could be considered as an alternative neuromuscular blockade reversal agent in patients with ESRD.

\section{Résumé}

Objectif Bien que le sugammadex (SGX) ne compte pas parmi ses indications une utilisation chez les patients atteints d'insuffisance rénale terminale (IRT), son administration à cette population de patients est rapportée. Nous avons conçu cette étude afin de passer en revue tous les cas de patients atteints d'IRT ayant reçu du SGX et décrire leurs devenirs cliniques.

Méthode Il s'agit d'une étude de cohorte historique portant sur 219 patients atteints d'insuffisance rénale chronique de stade 5 ayant reçu du SGX dans l'un de trois hôpitaux appartenant au même réseau de santé universitaire. Les données démographiques, les événements significatifs notés dans les dossiers anesthésiques et les complications postopératoires ont été colligés entre le 7 mars 2016 et le $1^{\text {er }}$ août 2019. Le critère d'évaluation principal incluait toute complication possiblement liée à l'utilisation de SGX telle qu'une réaction d'hypersensibilité, une réintubation, une hypoxémie, une pneumonie, et un bloc neuromusculaire résiduel. Les critères d'évaluation secondaires comprenaient toute autre complication non incluse dans notre critère d'évaluation principal et/ou la mortalité des patients dans les 30 jours suivant l'intervention.

Résultats Aucun patient n'a eu de réaction d'hypersensibilité. Trois patients ont dû être réintubés, et deux patients ont développé une hypoxémie qui n'a pas 
nécessité de réintubation. Un patient a contracté une pneumonie nosocomiale. Cinquante (23\%) patients ont souffert d'autres complications postopératoires (différentes de notre critère d'évaluation principal) et neuf patients (4\%) sont décédés au cours des 30 jours postopératoires subséquents. Aucun de nos critères d'évaluation primaire ou secondaires ne semblaient liés à l'utilisation de SGX.

Conclusion Nous proposons des données probantes supplémentaires selon lesquelles le SGX pourrait être envisagé comme agent décurarisant alternatif chez les patients atteints d'IRT.

Keywords neuromuscular blockade - sugammadex · end-stage renal disease $\cdot$ chronic kidney disease . patient safety

Sugammadex (SGX) is a modified cyclodextrin that antagonizes aminosteroidal neuromuscular blocking agents (NMBAs) through encapsulation. ${ }^{1,2}$ As the SGXNMBA complex forms, NMBA is pulled into the plasma from its site of action at the neuromuscular junction because of a concentration gradient. ${ }^{3-5}$ The SGX-NMBA complex is hydrophilic and is excreted unchanged into the urine. ${ }^{4,6}$ As a result of this pharmacokinetic property, the United States Food and Drug Administration does not recommend using SGX as an NMBA antagonist in patients with a creatinine clearance $<30 \mathrm{~mL} \cdot \mathrm{min}^{-1}$.

Sugammadex antagonizes neuromuscular blockade faster than neostigmine and reduces the risk of postoperative residual neuromuscular blockade. ${ }^{8,9}$ It also has the novel ability to reverse deep levels of neuromuscular blockade (train-of-four count $<1$ ) and 16 $\mathrm{mg} \cdot \mathrm{kg}^{-1} \mathrm{SGX}$ can rapidly restore neuromuscular function after $1.2 \mathrm{mg} \cdot \mathrm{kg}^{-1}$ rocuronium has been administered. ${ }^{9}$ As a result of this drug's novel applications and clinical efficacy, clinicians have expanded its use in various off-label scenarios such as in patients with significant renal impairment. ${ }^{2,5,10-16}$

In patients with reduced renal function, theoretical concerns include the effects of prolonged exposure to the SGX-NMBA complexes that remain within circulation. Cammu et al. have shown that standard convective and diffusive dialysis techniques can remove this complex. ${ }^{17}$ Nevertheless, neuromuscular blockade could recur if the circulating SGX-NMBA complex dissociates, allowing free NMBA to reach the neuromuscular junction. Additionally, delayed clearance of SGX-NMBA complex may increase the risk of hypersensitivity reactions. ${ }^{18}$ The use of neostigmine in patients with end-stage renal disease (ESRD) is also concerning as $50 \%$ of this drug is renally cleared, a characteristic that prolongs exposure to its undesired muscarinic effects. ${ }^{19}$

Anecdotally, we were familiar with SGX being used to successfully antagonize neuromuscular blockade in patients with ESRD. As such, we designed the current study to review all instances of patients receiving SGX with ESRD within our institution's health system and to describe their clinical outcomes.

\section{Methods}

After obtaining Institutional Review Board approval (22 August 2019), electronic medical records of adult (age $\geq$ 18 yr) patients with chronic kidney disease stage 5 (CKD5) who underwent general anesthesia and received intraoperative SGX were identified and reviewed (Figure). The list of patients with CKD5 identified through hospital International Classification of Diseases (ICD)-9/ICD-10 codes was cross-referenced with patients receiving SGX via pharmacy data from 7 March 2016 (when SGX became available on our institution's formulary) until 1 August 2019. Subjects who signed a waiver to exclude their medical records from research studies were excluded. CKD5 was defined, as per the National Kidney Foundation, ${ }^{20}$ as patients with glomerular filtration rate $(\mathrm{GFR}) \leq 15 \mathrm{~mL} \cdot \mathrm{min}^{-1}$, with or without the need for renal replacement therapy (RRT) at the time of the procedure. Each medical record was reviewed for preoperative, intraoperative, and postoperative data up to 30 days after surgery. Patient demographics, perioperative data, and postoperative events were collected and managed using REDCap electronic data capture tools hosted at our institution. $^{21}$

The primary outcome of the study was defined as complications that could be related to delayed clearance of SGX within 30 days following its administration. These complications included hypersensitivity reactions, the need for reintubation, hypoxemia, and pneumonia. Hypersensitivity reactions were defined as a constellation of clinical symptoms (rash, flushing, difficulty breathing, nausea, stomach discomfort, palpitations, tachycardia, hypotension, paresthesia, and visual disturbance) after administration of SGX. Need for reintubation was defined as any patient requiring endotracheal intubation within the next 30 postoperative days. Hypoxemia was defined as an oxygen saturation $(<92 \%)$ for more than five minutes measured by pulse oximetry while in the recovery room, evidence of hypoxemia discussed in hospital progress notes and discharge summaries, or oxygen arterial pressure $\leq 75$ $\mathrm{mmHg}$ measured in an arterial blood gas analysis. Pneumonia was defined as clinical signs and symptoms suggestive of respiratory infection and confirmed by 
laboratory or imaging studies (e.g., sputum culture and/or chest $x$-ray). Each electronic medical record of a patient who had any of these complications was examined to identify the cause and the possible association with SGX use. The secondary outcome was the identification by manual chart review of any other complication that could possibly be related to SGX administration and/or patient death up to 30 days after the procedure, independent of possible association with SGX.

\section{Statistical analysis}

An analysis was conducted using descriptive statistics. Continuous variables are presented using central tendency values, including mean (standard deviation [SD]) for normally distributed data and median [interquartile range (IQR)] for skewed distribution data. Categorical data are reported as frequencies and percentages $(\%)$.

\section{Results}

There were 543,142 general anesthesia cases performed throughout our health system at three distinct geographic locations (Scottsdale, AZ; Jacksonville, FL, USA; Rochester, MN, USA) during the period from 7 March 2016 to 1 August 2019. Sugammadex was used in 73,958 cases (7.3\%), 565 of which also had a diagnosis of CKD5 listed in their medical record. After excluding patients who did not have CKD5 at the time of the surgery or were $<18$ yr old, and one patient with an obvious charting error, 219 patients with CKD5 who received SGX were identified as our final study population (Figure).

The mean (SD) age in our study was 61.5 (14.1) yr and $82(37.4 \%)$ were female. Mean body mass index was 28.9 (6.8) $\mathrm{kg} \cdot \mathrm{m}^{-2}$. A total of $171(78.1 \%)$ patients required routine renal replacement therapy (RRT) at the time of the procedure, 143 patients (83.6\%) were on hemodialysis (HD), and 28 patients (16.4\%) were on peritoneal dialysis. The mean (SD) dose of SGX was 217 (106) $\mathrm{mg}$ or 2.7 (1.2) $\mathrm{mg} \cdot \mathrm{kg}^{-1}$ (Table 1).

Eighteen (8.2\%) of the 219 patients receiving SGX experienced 25 complications included in our primary outcome (Table 2) (Appendix 1). Thirteen (5.9\%) patients developed hypoxemia, 3 (1.4\%) developed pneumonia, and $9(4.1 \%)$ required reintubation within 30 days of the surgical procedure. No patients experienced a hypersensitivity reaction.

Five of the eight patients developed hypoxemia not requiring reintubation that appeared unrelated to SGX. Three of these patients developed hypoxemia not requiring reintubation after discharge and presented to the emergency room on postoperative day 17,18 , and 26 , respectively. One patient developed hypoxemia secondary to septic shock after undergoing emergent bowel resection. One patient developed hypoxemia not requiring reintubation on postoperative day 9 due to a large pleural effusion. Two patients developed hypoxemia not requiring reintubation after receiving SGX and before being dialyzed (Table 3). The etiology of hypoxemia in these patients was thought to be pulmonary edema and prolonged apnea, respectively.

Two of three patients developed pneumonia that appeared unrelated to SGX. One of these patients developed airway hemorrhage from an aortoesophageal fistula on postoperative day 4. One patient developed encephalopathy, septic shock, and aspirated on postoperative day 12. One patient developed hospitalacquired pneumonia three days after the procedure. While no evidence of aspiration was noted, adequate recovery from neuromuscular blockade was not confirmed as no quantitative monitor was utilized and residual weakness could be not excluded (Table 3).

Nine patients required reintubation that appeared to be unrelated to SGX in six patients. One patient developed hypoxemia after a tracheal stent became occluded. Two patients developed septic shock six and 14 days after the procedure, respectively. One patient developed hemorrhagic shock ten hours postoperatively. As previously mentioned, one patient had airway hemorrhage after a ligation of an aortoesophageal fistula on postoperative day 4. One patient developed a myocardial infarction on postoperative day 22 .

Three of the nine reintubations occurred before the patients were dialyzed. Although a careful chart review suggested that SGX was not implicated, this could not be definitively excluded (Table 3). One patient underwent a skin graft for a knee wound. The patient received $50 \mathrm{mg}$ of rocuronium at induction. At the conclusion of the operation $88 \mathrm{~min}$ later, $2 \mathrm{mg} \cdot \mathrm{kg}^{-1}$ of SGX were administered. In the postanesthesia care unit (PACU), the patient was reported to be unresponsive with an inadequate respiratory drive. Arterial gas analysis revealed hypercapnic respiratory failure and the patient needed to be reintubated $61 \mathrm{~min}$ after the initial extubation. A second patient underwent an inguinal hernia repair. After $40 \mathrm{mg}$ of rocuronium at induction, $5.6 \mathrm{mg} \cdot \mathrm{kg}^{-1}$ of SGX dose was administrated 120 min later. After extubation, the patient was noted to be somnolent and developed hypoxemia requiring reintubation $64 \mathrm{~min}$ after the initial extubation. The anesthesia providers documented that this respiratory failure may have been due to "residual anesthesia." In both cases, residual neuromuscular blockade could not be definitively excluded as a contributor to respiratory failure as no quantitative monitor was utilized to confirm adequate recovery. A third patient was reintubated after undergoing 
TABLE 1 Demographics

\begin{tabular}{|c|c|}
\hline Variable & Value \\
\hline Age (yr) & $61.5(14.1)$ \\
\hline Gender, female & $82(37.4 \%)$ \\
\hline Body mass index $\left(\mathrm{kg} \cdot \mathrm{m}^{-2}\right)$ & $28.9(6.8)$ \\
\hline \multicolumn{2}{|l|}{ Site } \\
\hline Arizona & $18(8.2)$ \\
\hline Florida & $106(48.4)$ \\
\hline Minnesota & $95(43.4)$ \\
\hline \multicolumn{2}{|l|}{ Race } \\
\hline Asian & $11(5)$ \\
\hline African American & $38(17.3)$ \\
\hline Native Hawaiian & $1(0.5)$ \\
\hline White & $165(75.3)$ \\
\hline Other & $2(0.9)$ \\
\hline Unknown & $2(0.9)$ \\
\hline \multicolumn{2}{|l|}{ CKD etiology } \\
\hline Diabetes & $51(23.3)$ \\
\hline Glomerulonephritis & $57(26.0)$ \\
\hline Hypertension/vascular disease & $25(11.4)$ \\
\hline Multiple/combined & $53(24.4)$ \\
\hline Structural disease/loss of renal mass & $19(8.7)$ \\
\hline Unknown & $14(6.4)$ \\
\hline \multicolumn{2}{|l|}{ Preoperative dialysis } \\
\hline Yes & $171(78.1)$ \\
\hline No & $48(21.9)$ \\
\hline \multicolumn{2}{|l|}{ Type of dialysis } \\
\hline Hemodialysis & $143(83.6)$ \\
\hline Peritoneal dialysis & $28(16.4)$ \\
\hline \multicolumn{2}{|l|}{ Type of procedure } \\
\hline Abdominal surgery & $49(22.4)$ \\
\hline Cardiothoracic surgery & $22(10.0)$ \\
\hline ENT surgery & $11(5.0)$ \\
\hline Neurosurgery & $3(1.4)$ \\
\hline OB/GYN surgery & $2(0.9)$ \\
\hline Ophthalmologic surgery & $1(0.5)$ \\
\hline Orthopedic surgery & $18(8.2)$ \\
\hline Plastic surgery & $4(1.8)$ \\
\hline Transplant surgery & $72(32.9)$ \\
\hline Kidney transplant & $70(31.9)$ \\
\hline Urologic surgery & $15(6.9)$ \\
\hline Vascular surgery & $22(10.0)$ \\
\hline
\end{tabular}

Values are $\mathrm{n}(\%)$, mean (standard deviation), unless otherwise indicated.

CKD = chronic kidney disease; ENT = ears, nose, and throat or otolaryngology; OB/GYN = obstetrics and gynecology .

a kidney transplant that required significant volume administration intraoperatively. After extubation, the patient developed hypoxemia and had to be reintubated
212 min after extubation. Chest radiograph was consistent with pulmonary edema. A quantitative neuromuscular monitor was utilized in this patient and although the anesthesia record documented train-of-four count of 4 at the conclusion of the operation, adequate recovery could not be verified as the train-of-four ratio from this quantitative monitor was not linked into the electronic medical record.

Fifty $(23 \%)$ patients developed our secondary outcome of any postoperative complication within the first 30 days following surgery. The most common included bleeding (5\%), need for transfusion of red blood cells (4.5\%), pulmonary edema (3.2\%), and arrhythmias (1.8\%) (Appendix 2). Finally, nine patients $(4.1 \%)$ died within 30 days of their operation (Appendix 3).

\section{Discussion}

In the current study, we found 18 of 219 patients (8.2\%) with CKD5 and SGX administration that required reintubation, developed hypoxemia, or pneumonia within the first 30 postoperative days. No patients experienced a hypersensitivity reaction. A careful review determined that complications related to neuromuscular blockade management could not be excluded in six of the 18 patients; however, the authors felt it to be unlikely. These results suggest that SGX can be used as an agent for reversing aminosteroidal-induced neuromuscular blockade in patients with CKD5.

The efficacy and safety profile of SGX in CKD patients has been evaluated in several small studies. ${ }^{2,10,11,17}$ Panhuizen et al. showed a complete, rapid, and welltolerated reversal of deep rocuronium blockade in patients with both normal renal function $(n=35)$ and $\operatorname{ESRD}(n=$ $35)^{2}$ While train-of-four ratio (TOFR) recovery from SGX is slower in patients with CKD when compared with patients with normal renal function [median recovery to TOFR 0.9 was 3.1 (95\% CI, 2.4 to 4.6 ) vs 1.9 (95\% CI, 1.6 to 2.8) min, respectively; $P=0.0002$ ], reversal still occurs faster than with neostigmine. De Souza et al. also evaluated the efficacy and safety of SGX in 20 patients undergoing kidney transplants who had CKD stages 4 and 5, compared with 20 patients without renal failure and concluded that although the mean (SD) recovery was slower in the CKD population [5.6 (3.6) min $v s 2.7$ (1.3) $\mathrm{min} ; P=0.003$ ], SGX was still effective and safe, reporting zero complications. ${ }^{10}$ While we cannot comment on the speed of reversal in our study, our results suggest a similar safety profile of SGX.

Sugammadex-induced hypersensitivity reactions have been reported and the concern has been raised about this being increased in patients with delayed renal clearance. ${ }^{11,18,22-25}$ Nevertheless, a large retrospective 
TABLE 2 Complications within 30 days after surgery

\begin{tabular}{ll}
\hline Variables & Values \\
\hline Primary outcome complication at 30 days & $18(8.2 \%)$ \\
Hypersensitivity reactions & $0(0 \%)$ \\
Need for reintubation & $9(4.1 \%)$ \\
Hypoxemia & $13(5.9 \%)$ \\
Pneumonia & $3(1.4 \%)$ \\
Mortality & $8(3.7 \%)$ \\
SGX-related mortality & $0(0 \%)$ \\
Any complication at 30 days & \\
Yes & $50(22.8 \%)$ \\
No & $169(77.2 \%)$ \\
\hline
\end{tabular}

SGX = sugammadex .

review from Japan of 15,479 patients found an extremely low $(0.039 \%)$ incidence of anaphylaxis possibly related to SGX use. $^{18}$ Similarly, Adams et al. conducted a retrospective observational study to evaluate SGX safety in 158 surgical patients with ESRD requiring RRT, and the results showed no cases of anaphylaxis. ${ }^{11}$ Our results are consistent with these previous efforts.

The recurrence of neuromuscular blockade has been described via possible dissociation of SGX from NMBA in the plasma. ${ }^{11}$ Sugammadex has a high association constant $\left(\mathrm{K}_{\mathrm{a}}\right)$ with rocuronium $\left(17,000-20,400 \mathrm{M}^{-1}\right)$, and a low dissociation rate constant $\left(\mathrm{K}_{2}=0.00216 \mathrm{~min}^{-1}\right){ }^{1,26}$ Such pharmacokinetics suggest that even if dissociation occurs, a rapid re-association is likely because of its strong binding force, leaving little free rocuronium available for restoring neuromuscular blockade. ${ }^{1,11,27}$ There is no evidence that this pharmacology is significantly altered in ESRD patients and prior work has failed to show recurrence of neuromuscular blockade 48 hours after SGX administration. ${ }^{2,5,12}$ We did not identify any cases of neuromuscular blockade recurrence in our study, although universal quantitative monitoring was not utilized in our study population.

Pulmonary complications, including hypoxemia, the need for reintubation, and pneumonia, are frequently related to residual NMB. ${ }^{5,28}$ Our incidence of $5.9 \%$ was slightly higher than the reported incidence of $3.1 \%$ in patients with GFR $<30 \mathrm{~mL} \cdot \mathrm{min}^{-1} \cdot 1.73 \mathrm{~m}{ }^{2,29}$ Moreover, the general incidence of any postoperative complication in CKD patients ranges from $15 \%$ to $64 \% .^{30,31}$ Our incidence of $22.8 \%$ is comparable with reported data of $23.5 \%$ of complications after 30 days of a major abdominal surgery in patients requiring hemodialysis. ${ }^{32}$ The overall reported mortality of CKD patients ranges from $1 \%$ in non-cardiac patients to up to $20 \%$ for cardiac patients. ${ }^{29,32-35}$ Our postoperative mortality of $4.1 \%$ was lower than previous descriptions of ESRD patients. While the present work cannot attribute reduced mortality to the use of SGX instead of neostigmine, SGX use has been associated with reductions in postoperative complications in patients with normal renal function. ${ }^{8,36}$

TABLE 3 Patients with complications occurring after sugammadex administration and prior to next scheduled dialysis

\begin{tabular}{|c|c|c|c|c|c|c|c|}
\hline $\begin{array}{l}\text { Age } \\
(\mathrm{yr})\end{array}$ & Sex & Procedure & NMBA & $\begin{array}{l}\text { Total } \\
\text { dose } \\
(\mathrm{mg})\end{array}$ & $\begin{array}{l}\text { Type of } \\
\text { NM } \\
\text { monitoring }\end{array}$ & $\begin{array}{l}\text { SGX dose } \\
\left(\mathrm{mg} \cdot \mathrm{kg}^{-1}\right)\end{array}$ & Brief description \\
\hline 51 & $\mathrm{~F}$ & $\begin{array}{l}\text { Split-thickness } \\
\text { skin graft }\end{array}$ & Roc & 50 & PNS & 2.0 & $\begin{array}{l}\text { Reintubated } 61 \text { min after extubation because of hypercapnic } \\
\text { respiratory failure }\end{array}$ \\
\hline 48 & M & $\begin{array}{l}\text { Inguinal hernia } \\
\text { repair }\end{array}$ & Roc & 40 & PNS & 5.6 & $\begin{array}{l}\text { Reintubated } 64 \text { min after extubation, anesthesia note suggests } \\
\text { "residual anesthesia" }\end{array}$ \\
\hline 33 & M & $\begin{array}{l}\text { Kidney } \\
\text { transplant }\end{array}$ & Roc & 85 & AMG & 2.4 & Reintubated 212 min after extubation because of pulmonary edema \\
\hline 63 & M & A-V fistulogram & Roc & 40 & PNS & 4.0 & $\begin{array}{l}37 \text { min after the procedure, the patient presented with hypoxemic } \\
\text { respiratory failure due to pulmonary edema. Patient was treated } \\
\text { with supplemental oxygen }\end{array}$ \\
\hline 69 & M & $\begin{array}{l}\text { Kidney } \\
\text { transplant }\end{array}$ & Roc & 100 & PNS & 2.0 & $\begin{array}{l}\text { Patient with history of OSA and central apnea. On POD \#1, patient } \\
\text { presented with hypoxemia due to several prolonged apneic } \\
\text { episodes, requiring BiPAP }\end{array}$ \\
\hline 48 & $\mathrm{~F}$ & $\begin{array}{l}\text { Laparoscopic } \\
\text { sleeve } \\
\text { gastrectomy }\end{array}$ & Roc & 130 & PNS & 2.0 & Hospital-acquired pneumonia POD \#3, no signs of aspiration \\
\hline
\end{tabular}

$\mathrm{AMG}=$ acceleromyography; $\mathrm{A}-\mathrm{V}=$ arteriovenous $; \mathrm{BiPAP}=$ bilevel positive airway pressure $\mathrm{NM}=$ neuromuscular; $\mathrm{NMBA}=$ neuromuscular blocker agent; $\mathrm{NMB}=$ neuromuscular blockade; NRB = non-rebreather mask; OSA = obstructive sleep apnea; PMH = past medical history; PNS = peripheral nerve stimulation; $\mathrm{POD}=$ postoperative day; Roc $=$ rocuronium; $\mathrm{SGX}=$ sugammadex. 
Total number of patients undergoing general anesthesia

(March 7, 2016 - August 1, 2019) $(\mathrm{n}=543,142)$

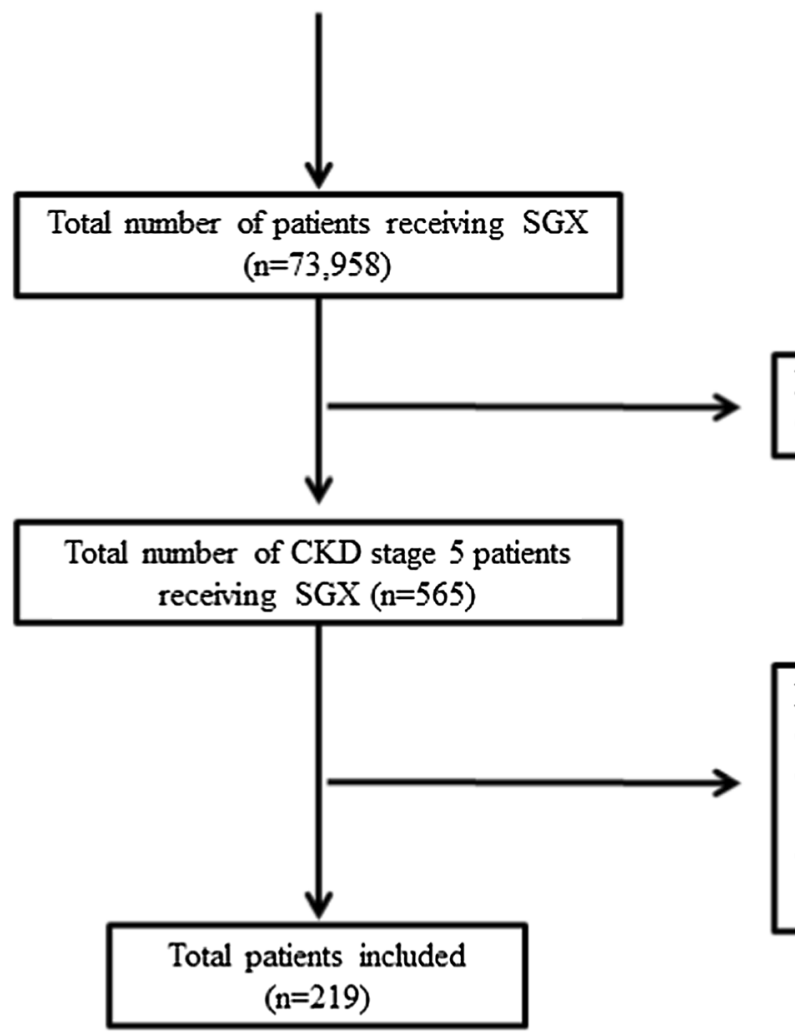

Patients excluded

- Patients without $\mathrm{CKD}$

Patients excluded:

- Age <18 years

- Patients without CKD stage 5 at the time of the procedure

- Incomplete/error in charted information about NMBA or SGX use

\section{CKD, Chronic Kidney Disease; SGX, Sugammadex; NMBA, Neuromuscular Blocker Agent}

FIGURE Selection process of final study population. $\mathrm{CKD}=$ chronic kidney disease; NMBA $=$ neuromuscular blocking agent; $\mathrm{SGX}=$ sugammadex.

This study was conducted at three distinct geographic locations within one health system. One site had a higher utilization of SGX in CKD5 patients per total number of anesthetics compared with the other two sites. Of note, this site frequently uses quantitative neuromuscular monitoring as a result of local interest and investigations related to NMBA and monitoring. Unfortunately, such objective measurements were not automatically transferred into the medical record at the time of the study, a shortcoming that has since been remedied. The authors agree with a recent consensus statement that recommends quantitative monitoring whenever a NMBA is administered. ${ }^{36}$ This practice would significantly reduce the risk of residual blockade-related complications, especially in vulnerable populations such as CKD patients.

There are multiple limitations to our study. First, the use of SGX in CKD5 patients should be considered "off- label". In March 2016, SGX was introduced to our hospital formulary and became a frequently utilized NMBA antagonist, even in patients with CKD. Additionally, this retrospective review is subject to the limitations of any chart review and we indeed discovered one obvious charting error, in which the provider documented 1/10 of the normal dose of SGX, and had to be excluded from the final data analysis. Also, this study is limited by a relatively small sample size $(n=219)$, and we investigated infrequent outcomes such as reintubation. Nevertheless, to our knowledge, this study represents the largest cohort and longest follow-up of patients with CKD5 receiving SGX. Finally, the lack of a historical cohort for comparison limits the ability to assess the complication rate of CKD5 patients who received SGX compared with those who received conventional reversal with neostigmine. 
In conclusion, 18 of 219 (8.2\%) patients with ESRD developed postoperative pneumonia, hypoxemia, or required reintubation after SGX administration. While the majority of these complications appeared unrelated to neuromuscular blockade management, we could not definitively exclude SGX as a contributing factor in six of the 18 patients. Nonetheless, we felt that it was unlikely that administering SGX to these patients with ESRD significantly contributed to their postoperative complications. We recommend the routine use of quantitative neuromuscular monitoring when NMBA are employed, an effective practice to reduce postoperative complications associated with NMB ${ }^{37}$ Prospective studies are needed to make recommendations about the clinical impact of SGX in ESRD. We provide incremental evidence that SGX could be considered as a neuromuscular blockade reversal agent in patients with ESRD.

Author contributions Stephania Paredes, Steven Porter, and J. Ross Renew contributed to all aspects of this manuscript, including study conception and design; acquisition, analysis, and interpretation of data; and drafting the article. Ivan Porter contributed to study conception, study design, and manuscript editing.

Disclosures JRR has completed industry-funded research (Merck Inc) with the funds going to his employer.

Funding statement None.

Editorial responsibility This submission was handled by Dr. Hilary P. Grocott, Editor-in-Chief, Canadian Journal of Anesthesia.

\section{APPENDIX 1: List of patients experiencing primary outcome complication}

\begin{tabular}{|c|c|c|c|c|}
\hline Patient & $\begin{array}{l}\text { Need for } \\
\text { reintubation } \\
(n=9)\end{array}$ & $\begin{array}{l}\text { Hypoxemia } \\
(n=13)\end{array}$ & $\begin{array}{l}\text { Pneumonia } \\
(n=3)\end{array}$ & Causes \\
\hline $\begin{array}{c}\text { Patient } \\
1\end{array}$ & & $X$ & & Volume overload \\
\hline $\begin{array}{l}\text { Patient } \\
2\end{array}$ & & $X$ & & Volume overload \\
\hline $\begin{array}{c}\text { Patient } \\
3\end{array}$ & & $X$ & & Volume overload \\
\hline $\begin{array}{l}\text { Patient } \\
4\end{array}$ & & $X$ & & Septic shock \\
\hline $\begin{array}{l}\text { Patient } \\
5\end{array}$ & & $X$ & & Pleural effusion \\
\hline $\begin{array}{l}\text { Patient } \\
6\end{array}$ & & $X$ & & Pulmonary edema \\
\hline $\begin{array}{c}\text { Patient } \\
7\end{array}$ & & $X$ & & Apneic episodes \\
\hline
\end{tabular}

Appendix continued

\begin{tabular}{|c|c|c|c|c|}
\hline Patient & $\begin{array}{l}\text { Need for } \\
\text { reintubation } \\
(n=9)\end{array}$ & $\begin{array}{l}\text { Hypoxemia } \\
(n=13)\end{array}$ & $\begin{array}{l}\text { Pneumonia } \\
(n=3)\end{array}$ & Causes \\
\hline $\begin{array}{l}\text { Patient } \\
8\end{array}$ & $X$ & $X$ & $X$ & Pneumonia \\
\hline $\begin{array}{l}\text { Patient } \\
\quad 9\end{array}$ & & & $X$ & $\begin{array}{l}\text { Aspiration } \\
\text { pneumonia at } \\
\text { postoperative } \\
\text { day } 12\end{array}$ \\
\hline $\begin{array}{l}\text { Patient } \\
10\end{array}$ & & $X$ & $X$ & $\begin{array}{l}\text { Hospital-acquired } \\
\text { pneumonia at } \\
\text { postoperative } \\
\text { day } 3\end{array}$ \\
\hline $\begin{array}{l}\text { Patient } \\
\quad 11\end{array}$ & $\mathrm{X}$ & $X$ & & $\begin{array}{l}\text { Tracheal stent } \\
\text { blockade }\end{array}$ \\
\hline $\begin{array}{l}\text { Patient } \\
12\end{array}$ & $\mathrm{X}$ & & & Septic shock \\
\hline $\begin{array}{c}\text { Patient } \\
13\end{array}$ & $\mathrm{X}$ & & & Septic shock \\
\hline $\begin{array}{c}\text { Patient } \\
14\end{array}$ & $X$ & & & $\begin{array}{l}\text { Hemorrhagic } \\
\text { shock }\end{array}$ \\
\hline $\begin{array}{l}\text { Patient } \\
15\end{array}$ & $\mathrm{X}$ & $X$ & & $\begin{array}{l}\text { Myocardial } \\
\text { infarction }\end{array}$ \\
\hline $\begin{array}{l}\text { Patient } \\
16\end{array}$ & $\mathrm{X}$ & $X$ & & $\begin{array}{l}\text { Hypercapnic } \\
\text { respiratory } \\
\text { failure }\end{array}$ \\
\hline $\begin{array}{l}\text { Patient } \\
17\end{array}$ & $\mathrm{X}$ & $X$ & & $\begin{array}{l}\text { Residual } \\
\text { anesthesia }\end{array}$ \\
\hline $\begin{array}{c}\text { Patient } \\
18\end{array}$ & $\mathrm{X}$ & & & Pulmonary edema \\
\hline
\end{tabular}

APPENDIX 2: All complications after 30 days of followup

\begin{tabular}{ll}
\hline & $n^{*}(\%)$ \\
\hline Pulmonary complications & $3(1.3)$ \\
Hypercapnic respiratory failure & $7(3.2)$ \\
Pulmonary edema & $1(0.5)$ \\
Prolonged apneic episodes & $1(0.5)$ \\
Occlusion of tracheal stent & $1(0.5)$ \\
Airway hemorrhage & \\
Cardiovascular complications & $2(0.9)$ \\
Myocardial infarction & $1(0.5)$ \\
Takotsubo cardiomyopathy & $4(1.8)$ \\
Arrhythmia & $1(0.5)$ \\
Acute heart failure decompensation & $1(0.5)$ \\
Endocarditis & \\
Surgical complications &
\end{tabular}




\begin{tabular}{ll} 
Appendix continued & \\
\hline & $n^{*}(\%)$ \\
\hline Dehiscence of surgical site & $2(0.9)$ \\
Bleeding & $11(5)$ \\
Need for transfusion after procedure & $10(4.5)$ \\
Residual anesthesia & $2(0.9)$ \\
Transplant complications & \\
Kidney transplant rejection & $2(0.9)$ \\
Pancreas transplant rejection & $1(0.5)$ \\
Infections & \\
Pneumonia & $2(0.9)$ \\
Respiratory syncytial virus & $1(0.5)$ \\
Clostridium difficile infection & $1(0.5)$ \\
Urinary tract infection & $2(0.9)$ \\
Sepsis & $2(0.9)$ \\
Neurologic complications & \\
Encephalopathy & $1(0.5)$ \\
Stroke & $1(0.5)$ \\
Gastrointestinal complications & \\
Intestinal ischemia & $1(0.5)$ \\
Falls & $1(0.5)$ \\
Total deaths after 30 days & $9(4.1)$ \\
\hline Pleas no & \\
\hline
\end{tabular}

*Please note that 50 patients experienced one of these 70 complications with some patients experiencing more than one of these complications

\section{APPENDIX 3: Causes of death at 30 days}

\begin{tabular}{ll}
\hline Cause of death & $n(\%)$ \\
\hline Septic shock & $2(0.9)$ \\
Gastrointestinal perforation & $1(0.5)$ \\
ESRD & $2(0.9)$ \\
Intestinal ischemia & $1(0.5)$ \\
Stroke & $1(0.5)$ \\
Aortoenteric fistula bleeding & $1(0.5)$ \\
Unknown cause* & $1(0.5)$ \\
\hline
\end{tabular}

ESRD $=$ end-stage renal disease.

*Patient died at an outside hospital.

\section{References}

1. Bom A, Bradley $M$, Cameron $K$, et al. A novel concept of reversing neuromuscular block: chemical encapsulation of rocuronium bromide by a cyclodextrin-based synthetic host. Angew Chem Int Ed Engl 2002; 41: 266-70.

2. Panhuizen IF, Gold SJ, Buerkle C, et al. Efficacy, safety and pharmacokinetics of sugammadex $4 \mathrm{mg} \mathrm{kg}^{-1}$ for reversal of deep neuromuscular blockade in patients with severe renal impairment. Br J Anaesth 2015; 114: 777-84.

3. Epemolu O, Bom A, Hope F, Mason R. Reversal of neuromuscular blockade and simultaneous increase in plasma rocuronium concentration after the intravenous infusion of the novel reversal agent Org 25969. Anesthesiology 2003; 99: 632-7.

4. Gijsenbergh $F$, Ramael $S$, Houwing $N$, van Iersel $T$. First human exposure of Org 25969, a novel agent to reverse the action of rocuronium bromide. Anesthesiology 2005; 103: 695-703.

5. Staals LM, Snoeck MM, Driessen JJ, et al. Reduced clearance of rocuronium and sugammadex in patients with severe to end-stage renal failure: a pharmacokinetic study. Br J Anaesth 2010; 104: 31-9.

6. Sparr HJ, Vermeyen KM, Beaufort AM, et al. Early reversal of profound rocuronium-induced neuromuscular blockade by sugammadex in a randomized multicenter study: efficacy, safety, and pharmacokinetics. Anesthesiology 2007; 106: 935-43.

7. Food and Drug Administration. BRIDION ${ }^{\circledR}$ (sugammadex) Injection, for intravenous use - 2015. Available from URL: https://www.accessdata.fda.gov/drugsatfda_docs/label/2015/ 022225lbl.pdf (accessed July 2020).

8. Hristovska AM, Duch $P$, Allingstrup $M$, Afshari A. The comparative efficacy and safety of sugammadex and neostigmine in reversing neuromuscular blockade in adults. A Cochrane systematic review with meta-analysis and trial sequential analysis. Anaesthesia 2018; 73: 631-41.

9. Carron M, Zarantonello F, Tellaroli P, Ori C. Efficacy and safety of sugammadex compared to neostigmine for reversal of neuromuscular blockade: a meta-analysis of randomized controlled trials. J Clin Anesth 2016; 35: 1-12.

10. de Souza CM, Tardelli MA, Tedesco H, et al. Efficacy and safety of sugammadex in the reversal of deep neuromuscular blockade induced by rocuronium in patients with end-stage renal disease: a comparative prospective clinical trial. Eur J Anaesthesiol 2015; 32: 681-6.

11. Adams DR, Tollinche LE, Yeoh CB, et al. Short-term safety and effectiveness of sugammadex for surgical patients with end-stage renal disease: a two-centre retrospective study. Anaesthesia 2020; 75: $348-52$.

12. Staals LM, Snoeck MM, Driessen JJ, Flockton EA, Heeringa M, Hunter JM. Multicentre, parallel-group, comparative trial evaluating the efficacy and safety of sugammadex in patients with end-stage renal failure or normal renal function. $\mathrm{Br} \mathrm{J}$ Anaesth 2008; 101: 492-7.

13. Navare SR, Garcia Medina O, Prielipp $R C$, Weinkauf $J L$. Sugammadex reversal of a large subcutaneous depot of rocuronium in a dialysis patient: a case report. A A Pract 2019; 12: $375-7$. 
14. Lobaz S, Sammut M, Damodaran A. Sugammadex rescue following prolonged rocuronium neuromuscular blockade with "recurarisation" in a patient with severe renal failure. BMJ Case Rep 2013; DOI: https://doi.org/10.1136/bcr-2012-007603.

15. Pfaff $K$, Tumin D, Tobias JD. Sugammadex for Reversal of Neuromuscular Blockade in a Patient With Renal Failure. J Pediatr Pharmacol Ther 2019; 24: 238-41.

16. Min KC, Lasseter KC, Marbury TC, et al. Pharmacokinetics of sugammadex in subjects with moderate and severe renal impairment. Int J Clin Pharmacol Ther 2017; 55: 746-52.

17. Сатmu $G$, Van Vlem B, van den Heuvel M, et al. Dialysability of sugammadex and its complex with rocuronium in intensive care patients with severe renal impairment. Br J Anaesth 2012; 109: 382-90.

18. Miyazaki $Y$, Sunaga $H$, Kida $K$, et al. Incidence of anaphylaxis associated with sugammadex. Anesth Analg 2018; 126: 1505-8.

19. Cronnelly R, Stanski DR, Miller RD, Sheiner LB, Sohn YJ. Renal function and the pharmacokinetics of neostigmine in anesthetized man. Anesthesiology 1979; 51: 222-6.

20. National Kidney Foundation. K/DOQI clinical practice guidelines for chronic kidney disease: evaluation, classification, and stratification. Am J Kidney Dis 2002; 39(2 Suppl 1): S1-266.

21. Harris PA, Taylor R, Minor BL, et al. The REDCap consortium: building an international community of software platform partners. J Biomed Inform 2019; DOI: https://doi.org/10.1016/j. jbi.2019.103208.

22. Min KC, Bondiskey P, Schulz V, et al. Hypersensitivity incidence after sugammadex administration in healthy subjects: a randomised controlled trial. Br J Anaesth 2018; 121: 749-57.

23. Takazawa T, Mitsuhata H, Mertes PM. Sugammadex and rocuronium-induced anaphylaxis. J Anesth 2016; 30: 290-7.

24. Takazawa T, Tomita Y, Yoshida N, et al. Three suspected cases of sugammadex-induced anaphylactic shock. BMC Anesthesiol 2014; DOI: https://doi.org/10.1186/1471-2253-14-92.

25. Yoo JH, Kim SI, Ok SY, et al. Suspected anaphylactic reaction associated with sugammadex: a case report. Korean J Anesthesiol 2016; 69: 413-6.
26. Ploeger BA, Smeets J, Strougo A, et al. Pharmacokineticpharmacodynamic model for the reversal of neuromuscular blockade by sugammadex. Anesthesiology 2009; 110: 95-105.

27. Naguib M. Sugammadex: another milestone in clinical neuromuscular pharmacology. Anesth Analg 2007; 104: 575-81.

28. Murphy GS, Brull SJ. Residual neuromuscular block: lessons unlearned. Part I: definitions, incidence, and adverse physiologic effects of residual neuromuscular block. Anesth Analg 2010; 111: 120-8.

29. Sidawy AN, Aidinian G, Johnson ON 3rd, White PW, DeZee KJ, Henderson $W G$. Effect of chronic renal insufficiency on outcomes of carotid endarterectomy. J Vasc Surg 2008; 48: 1423-30.

30. Kellerman PS. Perioperative care of the renal patient. Arch Intern Med 1994; 154: 1674-88.

31. Schreiber S, Korzets A, Powsner E, Wolloch Y. Surgery in chronic dialysis patients. Isr J Med Sci 1995; 31: 479-83.

32. Cloyd JM, Ma Y, Morton JM, Kurella Tamura M, Poultsides GA, Visser $B C$. Does chronic kidney disease affect outcomes after major abdominal surgery? Results from the National Surgical Quality Improvement Program. J Gastrointest Surg 2014; 18: 605-12.

33. Horst M, Mehlhorn U, Hoerstrup SP, Suedkamp M, de Vivie ER. Cardiac surgery in patients with end-stage renal disease: 10-year experience. Ann Thorac Surg 2000; 69: 96-101.

34. Borlase B, Simon JS, Hermann G. Abdominal surgery in patients undergoing chronic hemodialysis. Surgery 1987; 102: 15-8.

35. Krishnan $M$. Preoperative care of patients with kidney disease. Am Fam Physician 2002; 66: 1471-6.

36. Jones RK, Caldwell JE, Brull SJ, Soto RG. Reversal of profound rocuronium-induced blockade with sugammadex: a randomized comparison with neostigmine. Anesthesiology 2008; 109: 816-24.

37. Naguib M, Brull SJ, Kopman AF, et al. Consensus statement on perioperative use of neuromuscular monitoring. Anesth Analg 2018; 127: 71-80.

Publisher's Note Springer Nature remains neutral with regard to jurisdictional claims in published maps and institutional affiliations. 